\title{
ENCOUNTERS AND IMPRESSIONS DURING MORE THAN HALF A CENTURY. ${ }^{1}$
}

God had ordained that 1 had to live in and serve many countries in every continent; but more expecially Europe and South East Asia. My life experiences of more than a half-century have taught me the absolute need for the European, with his higher culture and way of life, to live in complete separation or "apartheid" from the natives of Asiatic and African countries; not because they are black or brown or yellow, but because the enviromment in which they have grown up has produced types of a lower standard of morality and culture.

The white man is in the minority and it is just plain wishful thinking when he thinks that the native will be attracted to his higher standard of culture and within a generation or two his standards will be the same as that of the white man's. This is the opinion of our liberals and those who have no conception of the enormous gulf that exists between the groups or races who are the products of their own particular environments.

Men throughout the world and also in our own country, who malign us for our policy of "apartheid" are not necessarily bad men out to harm our country. Some of them are high placed Churchmen who honestly anink that they are performing a high religious service by preaching equality in social and political life, not knowing that it would be easier to mix oil and water than to mix together the products, especially of our high Western culture and morality. We have two excellent examples of what would inevitably happen, where a white minority gives power to a black majority of another culture, in India and Indonesia. The aim of the British and Dutch was to raise the standard of the native to that of the European. Both nations failed lamentably. The efforts of centuries ended in a very sad manner by the European being thrown out of these countries and their languages, which had been for two or three centuries the official languages respectively of the two countries, being also thrown out; completely in the case of Holland, and in the case of England, being in the process of being thrown nut. I have just read in a reliable newspaper

1. Dr. A. H. Ernst, skrywer van meegaande artikcl, is in 1890 in Ceylon gebore, uit Duitsc ouers. Hy het daar afgestudeer as geneesheer. In die Eerste Wêreldoorlog was hy vloot-sjirurg en het hy in Europa gedien in die R.A.M.C In 1917 is hy baie ernstig gewond. Later het hy aan die oorlog deelgenecm as geneesheer. In 1927 het hy die militêre diens verlaat en na Suid-Afrika gekom. Hy is tans 'n siturs-boer by Tzancen. 
that the only reason why English is still used in the Indian House of Assembly is that the Dravidian races, the Tamils and Malayalis of the South, find it difficult to understand Hindu, which is the official language of India, and consequently, English has been allowed to exist for a period of ten years.

Here I would like to stress that the natives of the countries I have mentioned must not be confused with the natives of South Africa, without a trace of a culture or civilisation, not even a written language.. The natives of the South East Asian countries had a culture and civilisation when our forefathers were little more than savages, the difference, however, being that the old civilisations of the East remained static while our Western civilisation has been progressively advancingr, more particularly so after the fall of the Byzantine Empire.

During the three hundred years or so of European domination, the natives of the South East Asian countries served the European as if he were a superior being from another planet. The European himself remained for the most part completely aloof and gave his orders through his native subordinates. He was the judge, the magistrate and the civil servant as distinguished from the clerical servant, who was a native. In his home and in his club he was served by an army of servants in complete "apartheid". Why did the European react in such a manner? He did so in order to safeguard his higher culture and civilisation. He took every possible precaution to prevent himself or his children from going native. He was in the midst of another culture, the result of a totally different environment, and he did everything possible to save himself from being submerged in that vast sea of people of another culture, inferior to his own. If this was necessary in the South East Asian countries where the European had established himself, how much more is it necessary in this our South Africa, where we are in contact with a numerically superior mass of people who are not far removed from the savage?

I entirely agree with Dr. Ben Marais that there is no difference whatsoever between the different human races whatever the colour may be. There is no such thing as blue blood. In fact the blood has nothing to do with any possible inherited characteristics. We rather think in terms of chromosones today. An Einstein might be born to any race and, given the correct environment and training, he will rise to the highest possible; but if he does not get the correct environment, he may not rise higher than to be, say, the best drum-beater of his tribe.

Environment is the all-important factor which separates nations and races; and what a tremendous roble environment plays! We are all very 
definitely the products of our environment. To give an excellent illustration: In my youth I came across a West African negro who was a High Court Judge. This man was brought to England as a very small boy by Bishop Wilberforce and educated entirely there. He knew of no country but England. He was in every respect a very highly cultured Englishman if you did not take the colour of his skin into consideration, for he was very black.

Again, to give you another practical illustration, I must take you back to my youth when I was sitting with an Indian doctor, the product of a British University, in Mesopotamia, somewhere near Baghdad. I knew of the Indian caste system and I was telling him of my experience in India when I was called to see a case, the wife of an Indian officer in the Indian Army. I told him how there was a curtain drawn between me and my patient through which I could see nothing. Consequently, not only was I not allowed to touch the patient, but I could not even see her. All I could do was to put questions and from the answers that came from the other side of the curtain get some idea of the case history.. I told himthe Indian doctor--how utterly unsatisfactory it all was. To my utter amazement my Indian colleague answered me by saying that he would rather see his wife hacked to pieces than allow a male doctor to examine her, no matter how ill she was. Even a British University could not change this man, the product of a totally environment to ours.

Once during my sanitary rounds inspecting the military barracks, I had this extraordinary experience. The drinking water for the troops was stored in large clay pots. I found that somebody had removed the covers from the pots and the water was contaminated by numbers of sparrow's which generally congregate in India wherever there is water. I was explaining to the havildar, or sergeant--this happened to be the barracks of an Indian Sikh regiment-how unsatisfactory this state of affairs was, when by accident my hand touched one of the pots. The pot was immediately taken outside and broken to pieces. The excreta of sparrows could not pollute the water, but my touch did.

While today most people are agreed that the human race consists of one composite whole; that there is no difference whatsoever in the potentiality of physical and mental development and that colour means nothing, we must forever keep in mind the all-important part that environment plays in the development of races and cultures; and the grave danger of minorities with a higher culture being swamped by masses with a lowel or no culture at all. This is particularly true in our South Africa.

So far, through the wisdom of your forefathers, you have maintained yourself for three hundred years as a pure European race and preserved 
your Western civilisation. Never elsewhere in the whole world has a small European community done what you have achieved; and now come high-placed Churchmen from other lands and men of liberalistic leanings within your very ranks, to tell you that you are wrong and that your attitude to the native is inhuman and unchristian. Do not believe them. They are the ones that are misguided, not you. South Africa cannot go back; it must go forward with or without the rest of the world. England can play with fire, if she must, by allowing thousands of West Indian coloureds of a lower culture and environment to settle in their country; but you must be true to the wisdom of your ancestors who have preserved a White South Africa for you, and more important, our Western Civilisation.

We must, however, be fair to our natives. They must be given every possible opportunity to develop to the highest they are capable of, in their own areas. As they develop and become more and more civilised, the natives themselves will welcome such an arrangement. They will be proud to own a country of their own which they can run as they please so long as they conform to civilised standards.

For the peace, unity and good government of South Africa and for the development of a cohesive South African Nation it is as important as the separate development of the European and the Native, that the two principal white races of South Africa should come together with only one patriotism, and that for the land of their birth or adoption, as is the case in the U.S.A.

The history of South Africa is tragic and the worst of the tragedy is that so much of it had occurred during my own lifetime. Our country was not spared by the greed and pride of Empire development and painting the world red, that seized Britain more than any other country during the turn of the last century. You, the Afrikaners, fought against this with a courage almost superhuman, which brought down the admiration of the whole civilised world; but it ended not only with the loss of your independence, which was dearer to you than life, but you were faced with burnt homes and utter ruination everywhere; and, as if your cup of sorrow was not full enough, you had to see the dying of your women and children by the thousands, but more especially, of your young innocent children. With amazing powers of recuperation you have risen again and find yourselves once more a free and independent people; but although in social life the gap between the two peoples is slowly closing up, the bad days of Colonialism are not yet quite over and this will not be over until the people of British descent, like the descendants of the Dutch, German or French, 
give up their overseas ties and remain faithful to their homeland, South Africa.

It is my considered opinion that such a happy state of affairs could not be achieved unless we become a republic-a form of government so well known in South Africa. This will unite the two sections as nothing else would do. The question is what sort of republic we should aim at. One thing, I feel certain, that we must not have is an "Indian" Republic. A republic within the Commonwealth will not necessarily bring the two races together. The people of one race will maintain that the sovereign head for all is still the same head of state who lives 5,000 miles away, and will continue to call the Commonwealth the British Empire, with South Africa as a part thereof. So strong is the influence of the old Colonial System.

The only solution to prevent this division and bring the two races together, is by proclaiming a republic entirely removed from the Commonwealth, in which the language and other rights of the two races are respected. Any advantage we may possibly lose by leaving the British Commonwealth we will more than gain by entering into close treaty ties with Great Britain, the United States of America and all the important countries of Western Europe.

A. H. ERNST. 